venting latency. ${ }^{32}$ Whether the prevention of latency would be either practicable or desirable in human populations is another matter. It may be that latent virus helps to maintain the levels of virus-neutralising antibody-possibly as a result of reactivation of virus both with and without symptoms.

An interesting era in antiviral treatment is developing. Acyclovir seems set to become one of the first effective antiviral agents that can be given systemically in safety. It is almost certainly the forerunner of more.

Morag C Timbury

Titular Professor of Bacteriology,

Royal Infirmary,

Glasgow G4 OSF

1 Elion GB, Furman PA, Fyfe JA, de Miranda P, Beauchamp L, Schaeffer HJ. Selectivity of action of an antiherpetic agent, 9-(2-hydroxyethoxymethyl) guanine. Proc Natl Acad Sci, USA 1977;74:5716-20.

2 Schaeffer HJ, Beauchamp L, de Miranda P, Elion GB, Bauer DJ, Collins P. 9-(2-hydroxyethoxymethyl) guanine activity against viruses of the herpes group. Nature 1978;272:583-5.

${ }^{3}$ Centifanto YM, Kaufman HE. 9-(2-hydroxyethoxymethyl) guanine as an inhibitor of herpes simplex virus replication. Chemotherapy 1979;25: 279-81.

4 Collins P, Bauer DJ. The activity in vitro against herpes virus of 9-(2hydroxyethoxymethyl) guanine (acycloguanosine), a new antiviral agent. 7 Antimicrob Chemother 1979;5:431-6.

${ }^{5}$ De Clercq E, Descamps J, Maudgal PC, et al. Selective antiherpes activity of 5-(2-halogenovinyl)-2'-deoxyuridines and -2'-deoxycitidines. In: Collier HL, Oxford J, eds. Developments in antiviral therapy. London: Academic Press, 1980:29,33.

- Crumpacker CS, Schnipper LE, Zaia JA, Levin MJ. Growth inhibition by acycloguanosine of herpesviruses isolated from human infections. Antimicrob Agents Chemother 1979;15:642-5.

7 Tyms AS, Scamans EM, Naim HM. The in vitro activity of acyclovir and related compounds against cytomegalovirus infections. $\mathcal{f}$ Antimicrob Chemother $1981 ; 8: 65-72$.

8 Jones BR, Coster DJ, Fison PN, Thompson GM, Cobo LM, Falcon MG. Efficacy of acycloguanosine (Wellcome 248U) against herpes-simplex corneal ulcers. Lancet $1979 ; \mathrm{i}: 243-4$.

${ }^{9}$ Collum LMT, Benedict-Smith A, Hillary IB. Randomised double-blind trial of acyclovir and idoxuridine in dendritic corneal ulceration. $\mathrm{Br} \mathcal{F}$ Ophthalmol 1980;64:766-9.

10 Coster DJ, Wilhelmus KR, Michaud R, Jones BR. A comparison of acyclovir and idoxuridine as treatment for ulcerative herpetic keratitis. $\mathrm{Br} \mathcal{F}$ Ophthalmol 1980;64:763-5.

11 McGill J, Tormey P, Walker CB. Comparative trial of acyclovir and adenine arabinoside in the treatment of herpes simplex corneal ulcers. $B r \mathcal{F}$ Ophthalmol $1981 ; 65: 610-3$.

12 Spruance SL, Schnipper ER, Kern CS, et al. Treatment of herpes simplex labialis with acyclovir. Abs 20th Intersci Conf Antimicrob Agents and Chemother. 1980. 22-24 September. New Orleans, 1980, Abs 516.

${ }^{13}$ Corey L, Keeney RE, Remington MR, et al. Double blind trial of topical acyclovir in genital herpes simplex virus (HSV) infection. Abs 20th Intersci Conf Antimicrob Agents and Chemother. 1980. 22-24 September. New Orleans, 1980, Abs 515.

14 Corey L, Nahmias AJ, Guinan ME, Benedetti JK, Critchlow CW, Holmes KK. A trial of topical acyclovir in genital herpes simplex virus infections. N Engl f Med 1982;306:1313-9.

15 Myers MW, Glasgow LA, Galasso GJ. Summary of a workshop on antiviral agents for genital herpesvirus infections. 7 Infect Dis 1982;145:774-82.

${ }_{16}$ Mindel A, Adler MV, Sutherland S, Fiddian AP. Intravenous acyclovir treatment for primary genital herpes. Lancet $1982 ; \mathrm{i}: 697-700$.

17 Peterslund NA, Seyer-Hansen K, Ipsen J, Esmann V, Schonheyder H, Juhl H. Acyclovir in herpes zoster. Lancet 1981 ;ii :827-30.

18 Bean B, Braun C, Balfour HH Jr. Acyclovir therapy for acute herpes zoster. Lancet 1982 ;ii:118-21.

19 Chou S, Gallagher JG, Merigan TC. Controlled clinical trial of intravenous acyclovir in heart-transplant patients with mucocutaneous herpes simplex infections. Lancet $1981 ; \mathrm{i}: 1932-4$.

${ }^{20}$ Mitchell CD, Bean B, Gentry SR, Groth KE, Boen JR, Balfour HH Jr. Acyclovir therapy for mucocutaneous herpes simplex infections in immunocompromised patients. Lancet 1981 ; : 1389-92.

21 Saral R, Burns WH, Laskin OL, Santos GW, Lietman PS. Acyclovir prophylaxis of herpes-simplex-virus infections. $N$ Engl f Med $1981 ; 305$ : 63-7.

${ }^{22}$ Chapman JR, Brigden D. Transient renal impairment during intravenous acyclovir therapy. Lancet 1981 ;ii:1103.

${ }^{23}$ Selby PJ, Powles RL, Jameson B, et al. Parenteral acyclovir therapy for herpesvirus infections in man. Lancet 1979 ;ii:1267-70.

24 Laskin OL, Longstreth JA, Whelton A, et al. Acyclovir kinetics in endstage renal disease. Clin Pharmacol Ther 1982;31:594-601.

${ }^{25}$ Brigden D, Fiddian P, Rosling AE, Ravenscroft T. Acyclovir-a review of the preclinical and early clinical data of a new antiherpes drug. Antiviral Research 1981 ; :203-12.

${ }^{26}$ Brigden D, Fowle A, Rosling A. Acyclovir a new antiherpetic drug: early experience in man with systemically administered drug. In: Collier w IH, Oxford J, eds. Developments in antiviral therapy. London: Academic Press, 1980:53.

22 Nilsen AE, Aasen T, Halsos AM, et al. Efficacy of oral acyclovir in the treatment of initial and recurrent genital herpes. Lancet 1982;ii:571-3.

${ }^{28}$ Crumpacker CS, Schnipper LE, Marlowe SI, Kowalsky PN, Hershey BJ, Levin MJ. Resistance to antiviral drugs of herpes simplex virus isolated from a patient treated with acyclovir. $N$ Engl F Med 1982;306:343-6.

29 Burns WH, Saral R, Santos GW, et al. Isolation and characterisation of resistant herpes simplex virus after acyclovir therapy. Lancet 1982;i: 421-3.

${ }^{30}$ Parris DS, Harrington JE. Herpes simplex virus variants resistant to high concentrations of acyclovir exist in clinical isolates. Antimicrob Agents Chemother $1982 ; 22: 71-7$

${ }^{31}$ Field HJ, Darby G. Pathogenicity in mice of strains of herpes simplex virus which are resistant to acyclovir in vitro and in vivo. Antimicrob Agents Chemother 1980;17:209-16.

32 Field HJ, Bell SE, Elion GB, Nash AA, Wildy P. Effect of acycloguanosine treatment on acute and latent herpes simplex infections in mice. Antimicrob Agents Chemother 1979;15:554-61.

\section{Peer review weighed in the balance}

\begin{abstract}
"I know that the paper I have just sent in [to the Royal Society] is very original and of some importance, and I am equally sure that if it is referred to the judgment of my 'particular friend' $X$ that it will not be published. He won't be able to say a word against it, but he will pooh-pooh it to a dead certainty.

"You will ask with some wonderment, Why? Because for the last 20 years $\mathrm{X}$ has been regarded as the great authority on these matters, and has had no one to tread on his heels, until at last, I think, he has come to look upon the Natural World as his special preserve, and 'no poachers allowed.' So I must manoeuvre a little to get my poor memoir kept out of his hands."'
\end{abstract}

Is peer review, or refereeing, ${ }^{2}$ the "lynch pin of science,"3 or do its shortcomings and potential for abuse outweigh any merits? Certainly the practice has a long tradition, dating back to the early years of both the Transactions of the Royal Society and the fournal des Sçavans, ${ }^{4}$ and yet, for a system which is widely used throughout the scientific communitywhether for assessing articles for publication or applications for research grants-little research has been done into either the process or the outcome. Important questions have now been raised by an article published in the June issue of Behavioural and Brain Sciences. ${ }^{5}$ Its methods and results should provoke wider discussion; already, the journal has printed no fewer than 59 invited commentaries on the article, together with a final riposte from the authors.

Early, brief accounts of the study appeared some time ago, ${ }^{6}$ but the full details have only just been published, ${ }^{5}$ because the authors' own article was rejected by the first two journals to which it was submitted (Science and American Psychologist). From a sample of broadly based, highly cited psychological journals D P Peters and S J Ceci randomly selected 12 articles by respected authors at prestigious institutions and changed a number of minor details. In particular, they gave new, false names to the authors and their institutions (such as the Tri-Valley Center for Human Potential) and altered the titles of the articles, the text of the abstracts, and the opening paragraph of the introductions. They then resubmitted these slightly altered articles to the same 12 journals that had published them some 18-32 months previously. The editors 
and referees were not told about this project until either they detected that the manuscript had been resubmitted or when the study had been completed.

Only three of the 12 manuscripts were recognised as having been published previously; eight of the remaining nine articles were rejected on the second submission, the editors and two referees all agreeing on each occasion. The articles were largely rejected on the grounds of poor methods, statistical analyses, or writing, most editors and referees failing to recognise and comment that the articles had no originality. Given that most factors had remained constant over this period, Peters and Ceci make a good case for explaining that the adverse reception of the articles the second time round was due to the change in the authors' status and institutions. They conclude their article by reviewing some of the suggestions for improving peer review: a standard rating form with explicit criteria, and training referees; formal evaluation of referees by authors, editors, and outsiders; "open peer commentary," in which the authors of accepted articles respond openly to criticism, all of which is published together in its entirety; and "blind" refereeing, in which the names and affiliations of the authors are withheld from the referee.

Peters and Ceci's study may be criticised on several grounds, and the contributors to the symposium are not slow to do so. They chose a discipline whose journals have a high rejection rate (at $80 \%$ not as high as philosophy journals, which top the list with $90 \%$, but much higher than some of those in physics, where even for some highly regarded publications the proportion of declined articles is only 10-20\%). The number of articles they used was too small to provide statistically valid conclusions; indeed, the outcome might have been due to chance alone, particularly if the articles were of middling quality and there were no strong reasons for accepting or rejecting most of them. The articles studied in the trial were not the same as those originally submitted: the initial referees reviewed raw articles, unmodified scientifically after their reports and the editors' decision or textually after they had been subedited, and the subtle changes the two researchers introduced into the introductions may have made the articles more difficult to grasp than Peters and Ceci concede.

The design of the trial may also be faulted in that it did not include either articles from non-prestigious authors and institutions that had been accepted once, or those from equally highly regarded sources that had been rejected. Several commentators also criticise the ethical aspects, claiming that the waste of time by busy referees and editors was unjustified. Finally, their findings may be interpreted in ways other than the lack of a "Mathew effect"? ("to him that hath shall be given"-in other words, articles by famous people are accepted irrespective of quality). Thus top scientists tend to be found in top-ranking institutions doing first-class work, and certainly with ample opportunities for peer review from colleagues before articles are submitted to the editor.

This said, however, I believe that the paper by Peters and Ceci warrants yet further careful study and discussion, because enough of their points have been made by other workers to add to the feeling of unease that all is not well with peer review. In 1974, for example, Franz Ingelfinger, then editor of the New England Fournal of Medicine, showed that concordance between two referees on 496 articles was only just better than chance. ${ }^{8}$ Even then, such agreement arose because both concurred about the really bad papers. A similar trend has been shown by an analysis of grant applications for research to the National Sciences Foundation ${ }^{9}$ : again, about a quarter of the decisions could have been made by chance.

More attention should certainly be given to "blindness" (the author's identity hidden from the referee). When referees and authors shared membership of a national or institutional group, Michael Gordon found, the referees were likely to be less critical. ${ }^{10}$ Arising from a suggestion of sex discrimination in accepting articles for the fournal of the American Modern Language Association, blinding referees led to a dramatic increase in the acceptance rate of articles written by women. ${ }^{11}$ And Robert Resenthal shows in the symposium how after he had transferred his job from a less prestigious institution to Harvard he was able to publish 15-20 articles in mainstream journals, which had previously rejected them. ${ }^{12}$

If, then, peer review is imperfect how can it be made better -one of the questions considered at last week's meeting in Nottingham ( $p$ 1259). Training, payment, and feedback for assessors all have some role, though there are cogent practical objections to blinding-particularly, as Arnold Relman has recently pointed out, the difficulty of removing all traces of the authorship from the text, figures, and references. ${ }^{13}$ Moreover, referees are not the ultimate decision makers: this is the task of the editor (helped or not by regular discussion with an editorial committee, a valuable body whose role is not mentioned at all in the peer review symposium), and the editor is likely to be aware of the author's identity.

Possibly the best changes that could be made would be to diminish the load on the individual reviewer and also to select the right one- "right," that is, from the point of view of expert knowledge, analytical judgment, and freedom from bias. Peer review entails an enormous amount of work for the referees-Relman has estimated that each year the New England Fournal demands six or seven man-years of referees' time ${ }^{14}$ - and editors should remember that theirs is not the only journal asking for an individual assessor's help. In future choosing a referee on objective grounds may be made easier by using a computer, and in the next few months we plan to follow the lead of the editors of several American journals that already choose and monitor their assessors in this way. With the established system, having read a paper on its arrival at the office, an editor can (consciously or subconsciously) largely determine its fate by selecting a particular referee.

Perhaps, however, everybody is asking too much of peer review, and we can no more insist on certainty in refereeing than we can in ensuring the absence of pollution, the effectiveness of teaching, or the dependability of household goods. ${ }^{15}$ But the lesson of this symposium is that, given the uncertainties, as scientists we should no longer trot out the tired old phrases that peer review is the best method there is of selecting articles or research projects. We need hard evidence to this effect, especially the results of objective studies. Does refereeing really act as a gatekeeper or merely as a traffic policeman, directing articles elsewhere? Citation analysis is one objective means of determining an article's importance, ${ }^{16}$ so how do the impact factors of articles rejected by a journal compare with those of the ones it publishes? Are most articles that are eventually published changed after being rejected once or twice or are they printed unaltered ? And is peer review adequate for the middle of the road, unadventurous article, ${ }^{10}$ but hopeless for the one with new and challenging ideas?

The answers to such questions will not necessarily be comfortable. In a book published two years ago Kenneth Warren (who has done much to emphasise the importance of 
measuring quality in medical articles) described a study of publications on schistosomiasis. ${ }^{17}$ The articles were ranked in importance by a team of experts, and Warren found that, though the $B M \mathcal{F}$ (which has always used peer review) and the Lancet (which for this period did not) had published roughly an equal and large number of articles on the subject, the two journals were ranked near the bottom of the league table for quality (quite the reverse for their overall rating as measured by citation indexes and impact factors). Thus merely having a peer-review system is not enough: editors must ensure that it works. Was a previous editor of the Lancet, Sir Theodore Fox, ${ }^{18}$ really joking when he said in his Heath Clark lectures "When I divide the week's contributions into two piles-one that we are going to publish and the other that we are going to return-I wonder whether it would make any real difference to the journal or its readers if $I$ exchanged one pile for the other"? Editors and referees should start a rigorous audit of their practices so that Sir Theodore's question can be answered.

\section{STEPHEN LOCK} Editor, $B M \mathcal{F}$

${ }^{1}$ Huxley TH. 1900. Cited by Zuckerman H, Merton RK. Patterns of evaluation in science. Minerva 1971;9:66-100.

2 Though some have argued that "refereeing" should be used for assessment of unpublished work and "review" for that of published work (Mertinson A. Discussion after paper by Horrobin. Fournal of Research Communication Studies $1982 ; 3: 331$ ), the words are generally used interchangeably, as they are here.

${ }^{3}$ Ziman J. Cited by Mahoney MJ. Publication, politics, and scientific progress. Behavioural Brain Sciences 1982;5:220-1.

4 Zuckerman H, Merton RK. Patterns of evaluation in science. Minerva $1971 ; 9: 66-100$.

${ }^{5}$ Peters DP, Ceci SJ. Peer-review practices of psychological journals. Behavioural Brain Sciences 1982;5:187-95.

${ }^{6}$ Cherfas J. Cited by Harnad S. The fate of published articles, submitted again. Behavioural Brain Sciences 1982;5:199.

${ }^{7}$ Merton BK. Cited by Beaver DD. On the failure to detect previously published research. Behavioural Brain Sciences 1982;5:199-200 ("To him that hath shall be given.")

${ }^{8}$ Ingelfinger FJ. Peer review in biomedical publication. Am $\mathcal{F} \mathrm{Med} 1974$; $56: 686-92$.

${ }^{9}$ Cole S, Cole JR, Simon GA. Chance and consensus in peer review. Science $1981 ; 214: 881-6$.

10 Gordon M. A study of the evaluation of research papers by primary journals in the UK. Leicester: Primary Communications Research Centre, no date [1980].

11 Horrobin DF. Peer review: a philosophically faulty concept which is proving disastrous for science. Behavioural Brain Sciences 1982;5:217-8.

12 Rosenthal R. Reliability and bias in peer-review practices. Behavioural Brain Sciences 1982;5:235-6.

13 Relman A. Editorial review. $N$ Engl f Med $1982 ; 307: 899$.

14 Relman AS. Are journals really quality filters? In: Warren KS, ed. Scientific journals as a quality filter. New York: Rockefeller Foundation, 1979:54-60.

15 Clark AH. Luck, merit, and peer review. Science 1982;215:11.

${ }_{16}$ Garfield E. Cited by Goffman W. The ecology of the biomedical literature and information retrieval. In: Warren KS, ed. Coping with the biomedical literature. New York: Praeger, 1981.

17 Goffman W, Warren KS. Scientific information systems and the principles of selectivity. New York: Praeger, 1980.

18 Fox TF. Crisis in communication. London: Athlone Press, 1965.

\section{Graft-versus-host disease}

Bone marrow transplantation has gained an accepted place in the management of many intractable disorders. Several forms of leukaemia which respond poorly to conventional chemotherapy alone may be controlled by intensive chemotherapy followed by bone marrow transplantation. ${ }^{1}$ Similarly the outlook for aplastic anaemia has been transformed since this form of treatment was introduced: over half the patients receiving successful transplants recover bone marrow function. ${ }^{2}$ The range of disorders which may be potentially treated in this manner is enormous and includes any inborn deficiency diseases in which the progeny of bone marrow progenitorg cells or their product can correct the deficiency. Thus 3 metabolic disorders, immunodeficiency diseases, and inherited $\stackrel{\mathbb{Q}}{\varrho}$ red-cell defects ${ }^{3}$ may all come within the scope of bone ${ }^{c}$ marrow transplantation.

A major obstacle to successful transplantation is the threat of graft-versus-host disease. This reaction results primarily from an attack by the donor's immunologically reactive lymphocytes against the "foreign" antigens of the host, but." other immunological abnormalities contribute to the process. $\overrightarrow{\vec{F}}$ Graft-versus-host disease complicated some $70 \%$ of recordedo marrow transplantations up to $1975^{4}$ despite using HLA- 들 matched sibling donors and despite immunosuppression after $\frac{\overline{\bar{c}}}{\overline{0}}$ grafting. Only recipients of marrow from an identical twin or the patient's own stored (autologous) marrow are free fromo the risk of this complication. Thus the problem arises with $-\overrightarrow{0}$ most marrow transplants.

The main targets of graft-versus-host disease in man arew the skin, the gastrointestinal tract, and the liver. The severityo of the reaction, clinically and histologically, varies from mild 3 . to severe and provides the basis for a grading of 1 to 4.0 Grades 2 to 4 carry a mortality exceeding $75 \%$. The process may be acute or chronic.

The future success of marrow transplantation largely depends, therefore, on the extent to which graft-versus-host N disease can be prevented or at least modified. Two main ${ }_{\circ}^{+}$ strategies are being pursued. The first and most well-tried ${ }_{\omega}^{\circ}$ approach depends on immunosuppressive agents given ${ }^{\circ}$ prophylactically or to treat the established disorder. The most effective combination of drugs has yet to be determined. In a recent randomised trial for preventing acute graft-versus- $-\underline{\underline{D}}$ host disease patients with aplastic anaemia or malignant $\vec{\bullet}$ disease received matched marrow grafts from siblings. ㅇํ $^{\circ}$ Whereas graft-versus-host disease developed in 17 of $35^{\circ}$ patients receiving methotrexate alone as prophylactic immunosuppression, this incidence was reduced to seven of 32 patients receiving a combination of methotrexate, antithymocyte globulin, and prednisone. Not all trials of this kind, however, $\stackrel{\mathbb{Q}}{\varrho}$ have produced such favourable results; the outcome depends $\overrightarrow{\vec{\circ}}$ on factors such as the timing of immunosuppressive treatment 3 in relation to marrow grafting. This point has become apparent in trials of cyclosporin A ${ }^{6}$ This powerful immunosuppressive agent virtually prevented the development of acute graft-versus-host disease at least in the median seven months of the trial but did not influence the course of the established disease.

A related problem with bone marrow transplants is the $\frac{\delta}{3}$ threat of opportunistic infections. In one prospective study 31 of 78 recipients acquired gastrointestinal infection by adenovirus, rotavirus, coxsackievirus, or Clostridium difficile, ${ }^{7} \rightarrow$ and the importance of gastroenteritis caused by coxsackievirus $\frac{D}{2}$ has been emphasised in a similar study. ${ }^{8}$ The mortality from such infections is high. Cytomegalovirus infection is also a major cause of death, usually from interstitial pneumonitis. $\omega$ The infection is attributable in part to reactivation of latent infection and in part to virus transmitted by blood transfusion products including granulocytes. ${ }^{9}$ Susceptibility to infection@् appears to result from the initial immunosuppression rather 0 than from graft-versus-host disease, but the risks may be increased by any additional immunosuppressive measures needed to control this complication. Furthermore, many of $\stackrel{\mathbb{Q}}{\varrho}$ the immunopathological features of graft-versus-host disease are themselves attributable to reactivated infections.

The alternative approach to preventing graft-versus-host 